\title{
情報論的学習理論と機械学習研究会の紹介
}

山西 健司

東京大学

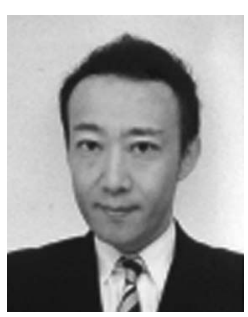

IBIS ワークショップは 2001 年より本学会の 第二種研究会「情報論的学習理論時限研究会」 (IBIS 研究会) となり，恒例のワークショップ開 催をメインに活動していた。これが 2006 年か ら International Workshop on Data-Mining and Statistical Science (DMSS) を主催していた人工 知能学会「データマイニングと統計数理研究会」 (SIG-DMSM) と, 2009 年から活動を共にするこ とにした。 そして，国内最大の機械学習及びデー タマイニングに関するコミュニティになることを 目指して設立したのが本研究会である。略称は IBIS に ML (Machine Learning)を加え，IBISML とした。

\section{IBISML 研究会が扱う分野}

本研究会で扱う分野は機械学習の基礎理論 から応用まで幅広くカバーする，以下に列挙し よう。

・機械学習の基礎理論：

情報論的基礎理論, 統計数理, 計算論的基礎 理論, 統計物理学的基礎理論

・機械学習の応用 :

データマイニング, 信号処理, メディア処理 (自然言語, 音声処理, 画像処理), パターン 認識・識別，バイオインフォマティクス，金 融工学, ロボット制御, セキュリティ, マー ケティング, ディペンダブルコンピューティン グ, Web/SNS 解析, 生命科学・脳科学への応 用，その他

理論においては，当初標榜していた「情報論 的」なアプローチにこだわることなく，広い範 囲のアプローチを受け入れている。応用分野に ついては，学習技術を軸にして，広い応用分野 との交流を促進している.

ロゴが左図であり，本分野の研究 者なら 1 度は目にしたことのある 図柄である，独自のロゴを持つ研 究会というのも珍しいであろう。 


\section{IBISML 研究会の目指すところ}

本研究会の活動方針を以下にまとめる.

1) 機械学習を通じた学際的な交流を図る

2) 若手にとって刺激的な情報発信の場を提供 する

3) 機械学習を通じて産学の連携を深める

4) 機械学習を通じた国際的交流の拠点となる 特に，ここでは 1)と 2)を強調しておこう。ま ず，1にについては，既に述べたように，機械学 習の応用分野は多岐にわたる。重要なのは，こ れらに共通する「学習」技術がどのようなトレ ンドをもって発展し, 関連し合っているかを, 横 断的な視点から追及していくことである。ある 応用分野で芽生えた学習技術が他の分野でも有 効かもしれない，そのようなことに気づくため の学際的交流を促進している.

2)については, 従来の IBIS ワークショップに は, 特に若手の研究者が本分野で活躍するため の登竜門としての位置づけがあった。本研究会 はその立場を受け継いで，若手研究者が自己ア ピールし，世界に羽ばたくきっかけを作る場に するべく努めている.

また，そのインセンティブとして IBISML 研 究会賞を設けている. 1 年間の研究会発表の中か ら研究専門委員会から優秀な論文を選出し, 年 度初回の研究会で表彰している。2010 年度研究 会賞には，

- 佐久間 淳 (筑波大 $/ \mathrm{JST}$ ) ・ 荒井 ひろみ（筑 波大)

「オンライン予測におけるプライバシ保護」

・竹内 一郎 (名工大)

「局所型パターン認識器の高次元特徵選択パス 追跡に関する一考察」

が選ばれている。

\section{IBISML 研究会の活動概況}

本研究会の活動の中心は，年 4 回（6月，9月， 11 月， 3 月）の研究会である。これまでは各回 100〜200 人規模の人数が参加している.

さらに, 毎年 11 月の研究会とリンクして, IBIS ワークショップを第二種研究会の形で開催
している，これは，招待講演とポスタープレゼ ンを主体とする，年に一度の機械学習分野の最 大の集会であり，例年 300 名程度が参加してい る、特にポスタープレゼンでは，論文になる前の Impromptu な話も議論できるような機会を与え ているのが特色である。このようなワークショッ プを本研究会と並行して走らせることは，本分 野を刺激する良いカンフル剂となっている.

また，2010～2011年度の他研究会との連携と して，9月の研究会を本学会のパターン認識・メ ディア理解研究会及び情報処理学会コンピュー タビジョンとイメージメディア研究会と共同開 催の形で行ってきた。国際会議への協賛実績と しては Asian Conference on Machine Learning (ACML), International Workshop on Data-Mining and Statistical Science (DMSS), Workshop on Learning with Logic and Logics for Learning (LLLL) がある.今後も本分野の国際会議や他 研究会との共催・協賛の機会を増やし, 主要会 議を日本に誘致する役割を果たしていきたい。

\section{5. 今後の IBISML 研究会の方向性}

今後, 本研究会のプレゼンスを益々高めてい きたい，その施策として以下の 2 つを挙げる.

A) チュートリアルを通じての啓蒙活動. 来年 より IBISML チュートリアルを第二種研究会活 動として行い, 本研究会とリンクさせることに した。これにより, 最先端の研究成果を発表す る機能だけではなく，機械学習が社会に幅広く 受け入れられるための地盤を整えていくことを 眓る。そうした啓蒙活動も重要と考える。

B) 日本独自の機械学習文化の創出. 本分野は 伝統的に欧米が強い. しかし, 本研究会は決し てそのフォロー研究会でも国際会議発表の予備 機関でもない。むしろ，日本独自の機械学習文 化を育む場となることを強く意識していきたい. 日本発の本分野の成果物を尊重し, 若い研究者 が自信を持つことができる舞台を創出していき たい。そのために,「情報論的学習」にまつわる テーマ的な国際的イベントの企画，雑誌の特集 への提案を積極的に行っていきたいと考える. 